\title{
The Effect of Institutional Ownership, Capital Structure, Dividend Policy, and Company's Growth on Firm Value (Study of Property Real Estate and Building Construction Companies)
}

\author{
Reza Mulia Sari ${ }^{1}$, Dina Patrisia ${ }^{2}$ \\ ${ }_{1}^{1}$ Universitas Negeri Padang, Padang, Indonesia, $\square$ rezamulisari@yahoo.com \\ 2Universitas Negeri Padang, Padang, Indonesia, $\square$ patrisiadina@yahoo.com
}

\begin{abstract}
This paper aims to examine whether the impact of institutional ownership, capital structure, dividend policy and company's growth on firm value. This study employed property real estate and building construction companies which are listed in The Indonesian Stock Exchange as the population. By using purposive sampling, we used 36 companies with observation period from 2012 to 2017 as the samples. We applied multiple linear regression as the data analysis tool. The results showed that the institutional ownership and company growth has no significant effect on company value, while the capital structure and dividend policies have positive impacts on firm value.
\end{abstract}

Keywords: Institutional ownership, capital structure, dividend policy, growth companies, and firm value

\section{Introduction}

One of the main objectives of go public companies is to enhance prosperity of the owners or shareholders by increasing corporate value (Salvatore, 2011). Whilst, the purpose of corporate financial management is to increase the value of the company, which is reflected in the stock price (Fama, 1978). Increasing company value means maximizing the wealth or welfare of shareholders. According to (Ghalandari, 2013) the value of each company could be related to share price so investors decide to invest by monitoring of firm value. According to (Alpi, 2017) the firm value is the investor's perception of the level of success of the company in managing resources. For the listed companies in the capital market, the stock price is an indicator of the company's value.

Firm value has significant role as high corporate value will be followed by high prosperity shareholders (Brigham \& Houston, 2011). The greater the ratio of PBV, the higher companies rated by investors. It can be concluded that the firm value is important information for investors because it is an indicator for the market to assess the company as a whole. When investors want to invest, investors will seek information in advance about the company to invest and choose which company is most profitable for investors. This study used firm value indicator namely price to book value (PBV). (Salvatore, 2011)mentions that there are several factors that affect firm value such as dividend policy, capital structure, the company's growth, ownership structure, investment decisions, and size of the company. This study will only focus on four factors considered dominant influence to firm value as institutional ownership, capital structure, dividend policy and the company's growth.

One of the main factors that influence firm value is institutional ownership. Institutional ownership according to (Gusti, 2013) is the ownership of shares of companies owned by institutions or institutions such as insurance companies, banks, investment companies and other institutional ownership. With high institutional ownership, institutional investors will have the opportunity to control the company. According to (Jensen \& Meckling, 1976) and (Sofyaningsih \& Hardiningsih, 2011) (Buchanan, Cao, \& Chen, 2018) the existence of an institutional investor is considered capable of being an effective monitoring mechanism in any decision taken by manager. A high level of institutional ownership will encourage institutional investors to conduct business greater scrutiny as well. It makes opportunistic behavior of managers can be prevented. In line with the opinion expressed by (Xiong, 2016) which says that institutional ownership (INST) can increase the firm value through participation in corporate governance and oversee the company's activities so that it will increase the value of the company. Because of this situation, agency problems arising between 
shareholders and managers can be minimized. Investors will get better ratings on companies whose shares are owned by institutional investors, and as result it will increase firm value. A study conducted by (Gusti, 2013) states that institutional ownership affected firm value. (Vintila \& Gherghina, 2014), (Sualehkhattak \& Hussain, 2017), (Ghalandari, 2013) and (Yuliyanti, 2014) conclude an effect of institutional ownership on firm value. On the other hand, (Isshaq, Bokpin, \& Onumah, 2009) and (Sugiarto, 2011) finds that there was no effect of institutional ownership to firm value.

The second factor that influences firm value is capital structure. Capital structure as stated by (Karadeniz et all, 2009) is balance or ratio between the amount of long-term debt and equity. According to the signalling theory the high debt level capital structure is used as a signal to distinguish good and bad companies. Only a healthy and strong company can pay off with the risks. (Myers, 1984) which states that capital structure can influence firm value. (Jensen, 1986) states that with debt, it can be used to control excessive free cash flow by management. The main sources that companies can use to meet their funds or finance are internal sources, namely equity, and external sources which can be in the form of debt. Most companies use a mixture of equity and debt that will form a capital structure (Nassar, 2016). Therefore, the capital structure is measured by the ratio of debt to equity (Seetanah et all, 2014). (Nawaz et all, 2011) said that capital structure theory explains that financial policies in determining a company's capital structure (a mixture of debt and equity) are intended to optimize the value of the company. The ratio commonly used to see the effect of loans from creditors both used as additional capital and sources of funds for the purchase of assets is the debt ratio, which is seen from the capital structure, namely Debt to Equity Ratio (Prasetia et all, 2018). Another research conducted by (Sujoko \& Soebiantoro, 2007) find that capital structure has a negative and significant impact to firm value. This research (Harahap \& Wardhani, 2011) and (Sugiarto, 2011) where capital structure does not affect firm value. However, (Sualehkhattak \& Hussain, 2017), (Adenugba et all, 2016), (Ghalandari, 2013), (Hasbi, 2015) and (Hermuningsih, 2013) find that positive effect of capital structure to firm value.

The third factor that influences firm value is dividend policy. Dividend policy according to (Rakhimsyah \& Gunawan, 2011) are policies on dividend payments are very important decisions in a company. According to (Titman et all, 2014) Dividend policy is a company decision in determining the amount of dividends and the time of dividend distribution to shareholders. This policy will involve two parties that have different interests, namely the first party of the shareholders and the second party of the company itself. Dividends is defined as payments to shareholders by the company for the profits they receive. The amount of dividend distributed by company may affect stock price, since according to theory of bird in the hand, investors prefer return coming from dividends compared with capital gains. This policy is often regarded as a signal to investors in assessing merits of a company's performance as well as a source of income for investors. According to signaling theory explaining that dividend policy has information content as a result company's policy to pay high dividends have positive information content for investors about the future profitability which will affect corporate value. High dividend distribution to shareholders is expected to corporate value will increase as well (Rachman, 2016). According to (Abidin et all, 2014), and (Rakhimsyah \& Gunawan, 2011) conclude that dividend policy adversely affect firm value. While a study conducted by (Ghalandari, 2013), (Sugiarto, 2011) , (Rizqia et all, 2013), (Artini \& Puspaningsih, 2011) state that a positive influence of dividend policy to firm value. In contrary, (Sualehkhattak \& Hussain, 2017) find that no effect of dividend policy to firm value.

The other factor is company growth. (Seftiani \& Ratih, 2011) state that company growth illustrates how investors respect to companies so investors are willing to invest their capital in the company. Growth is expressed as growth in total assets in order to see the growth of past assets which would reflect the future profitability. Company growth is a change (decrease or increase) in total assets owned by the company. The company's growth is expected by internal and external parties of a company because it can provide positive aspect for them. From the investor's point of view, the growth of a company is a sign that the company has a profitable aspect and they expect rate of return 
from their investment to provide better results. According to (Dhani \& Utama, 2017), companies with good asset growth are companies that are able to manage resources to generate profits so that they can add their own assets. Companies with large asset growth are companies that have good performance in generating profits so that they can increase company value. (Dewi \& Sudiartha, 2017) state that the increase in asset growth experienced by the company reflects that the company is in good performance so it experiences the development of company itself, this becomes a positive signal for investors to invest in the company, as a result the company's value will be high and it can be clearly seen on the stock price found in the company. This research (Sukriyawati, 2016), (Nadillah, 2017) where company growth does not affect firm value. However, Febrianti (2012), (Syardiana et al, 2015) dan (Rakhimsyah \& Gunawan, 2011) find that positive effect of company growth to firm value.

Based on above background, the researcher is very keen to conduct research entitle "The Effect of Institutional Ownership, Capital Structure, Dividend Policy, and Company Growth to Firm Values In Property Real Estate And Building Construction Companies Listed On The Indonesia Stock Exchange"

\section{Methods}

This paper aims to examine whether there is significant institutional ownership, capital structure, dividend policy and company's growth to firm value. Sample of this study uses purposive sampling method in order to obtain a final sample accounting 36 companies with observation period from 2012 to 2017. Type of data in this study is secondary data and uses multiple linear regression as an analytical tool.

\section{Results and Discussion}

Multiple linier regression analysis was used to determine the effect of institusional ownership, capital structure, dividend policy and company growth on firm value in property real estate companies and building construction listed on the indonesian stock exchange. From processing data with SPSS obtained as in the following table :

Table 1 The result of multiple regression

\begin{tabular}{|c|c|c|c|c|c|c|}
\hline Variable & $\begin{array}{c}\text { Regression } \\
\text { coefficient }\end{array}$ & $t$ count & sig. & $\begin{array}{c}R \\
\text { square }\end{array}$ & F count & Sig \\
\hline \multicolumn{7}{|c|}{ B } \\
\hline Constant & -6.079 & & & .208 & 13.833 & .000 \\
\hline Institusional ownership & .094 & 1.128 & .261 & & & \\
\hline Capital structure & .309 & 3.748 & .000 & & & \\
\hline Dividend policy & .270 & 4.114 & .000 & & & \\
\hline Company growth & .104 & 1.605 & .110 & & & \\
\hline
\end{tabular}

Source: Secondary Data Processed (2019)

From the table above can be determined the multiple regression equation as follows :

$$
\begin{gathered}
Y=a+b_{1} X_{1}+b_{2} X_{2}+b_{3} X_{3}+b_{4} X_{4} \\
Y=-6.079+0.094+0.309+0.270+0.104
\end{gathered}
$$

Where :

$\mathrm{Y}=$ Firm Value

a $\quad=$ Constanta

$\mathrm{b}=$ = Regression coefficient

$\mathrm{X}_{1} \quad=$ Institusional ownership

$\mathrm{X}_{2} \quad=$ Capital structure

$\mathrm{X}_{3} \quad=$ Dividend policy

$\mathrm{X}_{4} \quad=$ Company growth

e $\quad=$ Other factors not examined 
Based on the regression equation above, it can be interpreted as follows:

1. The amount of constant obtained is $-6,079$, without the existence of independent variables namel institutional ownership (X1), capital structure (X2), dividend policy (X3), and company growth $(\mathrm{X} 4)$, and then the company value $(\mathrm{Y})$ is $-6,079$.

2. The regression coefficient (b) of the institutional ownership variable (X1) obtained is positive which is 0.094 , it indicates that each improvement of institutional ownership variable to one point, and then it will result in an increase of company value approximately 0.094 point.

3. The regression coefficient (b) of the capital structure variable (X2) obtained is positive which is 0.309 , it indicates that each improvement of capital structure variable to one point, and then it will result in an increase of company value approximately 0.309 point.

4. The regression coefficient (b) of the dividend policy variable (X3) obtained is positive which is 0.270 , it indicates that each improvement of dividend policy variable to one point, and then it will result in an increase of company value approximately 0.270 point.

5. The regression coefficient (b) of the company growth variable (X4) obtained is positive which is 0.104, it indicates that each improvement of company growth variable to one point, and then it will result in an increase of company value approximately 0.104 point.

\section{Feasibility Test}

From the feasibility test, the F count is 13,883 with sig $0,000<0,05$. It means that from the $\mathrm{F}$ test carried out together with exogenous variables whose positive and significant influence to company value, as a result that the exogenous variables together have positive and significant relationship to the endogenous variables.

The coefficient of determination is needed to see how big the dependent variable $(X)$ to the independent variable $(\mathrm{Y})$. Calculated by squaring a predetermined assessment coefficient. Based on table 1, the contribution of institutional ownership variables, capital structure, dividend policy and company growth to firm value is $21 \%$, and the remaining $79 \%$ of the firm's value variable is given by other unidentified factors such as profitability, activities and others.

\section{Hypothesis Testing}

Hypothesis 1

Institutional ownership affects the company value in property real estate and building construction companies listed on the Indonesia Stock Exchange. Based on the analysis test results, it is known that Sig. 0.261> 0.05). It means that H0 is accepted and Ha is rejected, so the alternative hypothesis proposed in the study is rejected, so institutional ownership does not affect the value of the company.

Hypothesis 2

Capital structure affects the company value in property real estate and building construction companies listed on the Indonesia Stock Exchange. Based on the analysis test results, it is known that Sig. $0.000<0.05)$. It means that $\mathrm{HO}$ is rejected and $\mathrm{Ha}$ is accepted, so the alternative hypothesis proposed in the study is accepted, so capital structure affect the value of the company. Hypothesis 3

Dividend policy affects the company value in property real estate and building construction companies listed on the Indonesia Stock Exchange. Based on the analysis test results, it is known that Sig. $0.000<0.05)$. It means that HO is rejected and Ha is accepted, so the alternative hypothesis proposed in the study is accepted, so dividend policy affect the value of the company.

\section{Hypothesis 4}

Company growth affects the company value in property real estate and building construction companies listed on the Indonesia Stock Exchange. Based on the analysis test results, it is known that Sig. $0.100>0.05$ ). It means that $\mathrm{HO}$ is accepted and $\mathrm{Ha}$ is rejected, so the alternative hypothesis proposed in the study is accepted, so company growth does not affect the value of the company. 


\section{The Effect of Institutional Ownership on Company Values on Property, Real Estate and building Construction Companies which is listed in Indonesia Stock Exchange}

Based on the submission of the first hypothesis in Table 1, it was found that institutional ownership variables did not affect the company value of property real estate companies and building construction listed on the Indonesia Stock Exchange (IDX). The results obtained indicate that the size of the proportion of institutional share ownership in the company would not affect changes in company value. The results obtained were due to the relatively small proportion of institutional ownership in each company, as a result the function of the existence of institutional ownership was not going well, so it could not affect changes in company value measured by price to book value especially in real estate property and building construction on the Indonesia Stock Exchange. The small proportion owned by institutional investors makes them have a small role to carry out monitoring activities on internal activities, consequently monitoring or supervision activities are rarely carried out, and implementation is carried out at an unsustainable timeframe, which results in institutional investors not influencing company value.

The results of this study contradicted to the agency theory stating that one way that can be used to reduce agency problem and agency cost is by increasing institutional ownership of the company, because the ownership of institutional investors such as insurance companies, investment banks and other institutions that are shaped like companies would encourage management improvement supervision that is more optimal in managing the company (Moh'd et all, 1998). The results obtained in this study are in line with the opinion of (Sofyaningsih \& Hardiningsih, 2011) which proves that institutional ownership is not proven to affect company value. This happens because of the information asymmetry between investors and managers so that managers are difficult to control by institutional investors. The same results are also obtained in the study of (Aditya \& Supriyono, 2014) find that institutional ownership do not affect the value of the company. This is due to the fact that the large or small institutional ownership of the company has not been able to control and supervise the opportunistic actions of managers in running the company, on the other words institutional investors cannot optimize their control functions. Likewise with the results of the study conducted by(Isshaq et al., 2009), (Widyaningsih, 2018), and (Abdullah et all, 2017) study, each study reveals that institutional ownership is not a variable affecting company value.

\section{The Effect of Capital Ownership on Company Values on Property, Real Estate and building} Construction Companies which is listed in Indonesia Stock Exchange

Based on the second hypothesis testing result in Table 1, it is found that the capital structure as measured by the Debt to Equity Ratio has a positive and significant effect on company value. Companies that use debt in their operational activities will give a positive signal to investors because companies that use debt bravely means that the company believes that they can pay off their debts and manage debts as well as possible to produce a good investment activity in the company. As a result, the higher the capital structure (debt to equity ratio), the more increase of company value.

The result of this study supports the statement from (Modigliani \& Miller, 1963) which states that by including corporate income tax, the use of debt will increase the company value, because the cost of debt interest is cost that reduces tax payments. The higher the debt of a company, the higher the interest cost. The amount of interest costs can increase the reduction of income, so that the taxes paid will also be smaller. In addition, the signaling theory states that financing obtained through debt or with its own capital can provide a signal providing guidance to investors. This signal will be used by investors to assess good and bad corporate prospects in the future. Only healthy and strong companies can be liable by taking the risk. So, the signal will affect company value.

The results of this study is supported by (Yando, 2018), where the results of his research found that the capital structure had a positive and significant effect on company value. This can indicate that the management of the company is able to pay a balance or comparison of company capital originating from the source of debt (creditors) and at the same time the share of equity from the owner (equity) to create company value reflects a balance that is both absolute and relative. This 
research is also supported by (Wardhani et all, 2017), (Yuniati et all, 2016), (Pratiwi \& Mertha, 2017) and (Prastuti \& Sudiartha, 2016) which find that capital structure has a positive and significant effect on company value.

The Effects of Dividend Policy on Company Values on Property, Real Estate and building Construction Companies which is listed in Indonesia Stock Exchange.

Based on the third hypothesis testing results as in Table 1, it is found that the dividend policy measured by dividend payout ratio has a positive and significant effect on company value. Dividend policy is an important aspect that aims to maximize company value. This dividend policy relates to the policy on how much profit of the company to be distributed to shareholders. With the positive influence of the dividend payout ratio variable on company value, the greater the dividend paid to shareholders will cause the higher the company value. The amount of dividends distributed by companies can affect stock prices, with high stock prices and followed by companies distributing dividends consistently will attract investors to invest their funds in the company so that the company value in the view of investors is higher.

The results of this study are in line with the theory of bird in the hand, where investors prefer returns derived from dividends compared to capital gains. This policy is often seen as a signal for investors in assessing the bad performance of a company and being a source of income for investors. This research is also supported by the signaling theory that this theory explains that dividend policy has information content and can be used as a sign for investors in the company's cash flow in the future. The company's policy of paying high dividends has a positive information content (positive signal) for investors about future profitability and free cash flow that will affect the company value.

The results of this study are in line with (Ayem \& Nugroho, 2016) who state that the greater the profit distributed to shareholders, the greater investor interest in the company so it increases the company value. The result of this study is also supported a study conducted (Wardhani et al., 2017),(Jiang, 2012), (Rizqia et all, 2013), (Yuniati et all, 2016), (Febrianti, 2012), (Artini \& Puspaningsih, 2011), (Aditya \& Supriyono, 2014), (Ghalandari, 2013) and (Prastuti \& Sudiartha, 2016) found that dividend policy has a positive and significant effect on company value. It can be concluded that the market will assume the increase in dividends is a sign of an increase in the performance of the company for current and the future situation.

The Effect of Company Growth on Ownership on Company Values on Property, Real Estate and building Construction Companies which is listed in Indonesia Stock Exchange

Based on the fourth hypothesis testing result as in Table 1, it is found that company growth as measured by growth assets do not affect the company value. This study shows that the high and low growth of assets cannot be used to assess a company. That is because assets that are too high in the company show unproductive assets that cannot generate high profits. And also supported because investors not only see from the high and low growth of assets owned by the company, but more to the operations of the company's active company and the good performance of the company's management will be reflected in the financial statements will be more beneficial for investors in making decisions whether to invest or not. Investors trust companies that are already established and not growing. Therefore, if the company's growth is high, it will not affect the investor's confidence so it can be concluded that the company's growth does not affect the company value. The result of this study is supported by (Dhani \& Utama, 2017) a study conducted by (Sukriyawati, 2016), (Nadillah, 2017) found that company growth does not affect the company value.

\section{Conclusion}

Based on the analysis and discussion result of institutional ownership, capital structure, dividend policy and company growth to company values in property real estate and building construction companies listed on the Indonesia Stock Exchange, on the conclusion note about institutional ownership and company growth do not affect company value, while the capital structure variables 
and dividend policies have a positive effect on company value. Based on the study result that has been put forward, then to increase the company value, the researcher suggests: (1). On institutional ownership variables, for shareholders or external parties are expected to further improve the routine of monitoring activities to be carried out, such as empowering the institutional investors function, empowering the monitoring function that will make the internal parties' movements especially managers more limited so it can make limitation of scope for managers fraud, therefore increasing the role of monitoring carried out by institutional investors will further increase the company value observed from $t$ price to book value (2). In the capital structure (debt to equity ratio) the determination of capital structure by using debt at a certain level (as long as greater benefits, additional debt is still allowed) as a source of funding which can increase the company value. (3). The dividend policy variable is very important in determining the progress and survival of the company. One of the decisions is to take a dividend policy that shares profits with shareholders in the form of dividends that can increase the company value. In addition, company management is expected to be able to do good cash management so that the amount of cash is very well as a result, the amount of company cash is not excessive or deficient and adjusted to the company circumstances. (4). In the company's growth variable, the value is still low so that the company is advised to pay attention to the company growth rate, because investors also see companies whose high growth rates that can manage the company itself. Thus, investors take more consideration for investment decisions.

\section{References}

Abdullah, N. A. I. N., Ali, M. M., \& Haron, N. H. (2017). Ownership Structure , Firm Value And Growth Opportunities: Malaysian Evidence. American Scientific Publishers, (August). Https://Doi.Org/10.1166/Asl.2017.9479

Abidin, Z., Yusniar, M. W., \& Ziyad, M. (2014). Pengaruh Struktur Modal, Kebijakan Dividen Dan Size Terhadap Nilai Perusahaan (Studi Pada Perusahaan Properti Di Bursa Efek Indonesia). Jurnal Wawasan Manajemen, 2(3), 91-102.

Adenugba, A. A., Ige, A. A., \& Kesinro, O. R. (2016). Financial Leverage And Firms' Value: A Study Of Selected Firms In Nigeria. European Journal Of Research And Reflection In Management Sciences, 4(1), 14-32. Retrieved From Www.Idpublications.Org

Aditya, D., \& Supriyono, E. (2014). Pengaruh Profitabilitas Dan Kepemilikan Institusional Terhadap Nilai Perusahaan Dengan Kebijakan Dividen Sebagai Variabel Intervening Pada Perusahaan Manufaktur Yang Terdaftar Di Bursa Efek Indonesia, 307-326.

Alpi, M. F. (2017). Studi Kebijakan Hutang : Anta Seden Dan Dampaknya Terhadap Nilai Perusahaan. Jurnal Riset Finansial Bisnis, 1(2), 9-20. Https://Doi.Org/10.5281/Zenodo.1034686

Artini, L. G. S., \& Puspaningsih, N. L. A. (2011). "Struktur Kepemilikan Dan Struktur Modal Terhadap Kebijakan Dividen Dan Nilai Perusahaan". Keuangan Dan Perbankan, 15(1), 66-75.

Ayem, S., \& Nugroho, R. (2016). Pengaruh Profitabilitas, Struktur Modal, Kebijakan Deviden, Dan Keputusan Investasi Terhadap Nilai Perusahaan. Jurnal Akuntansi, 4(1), 31-39.

Brigham, E. F., \& Houston, J. F. (2011). Dasar-Dasar Manajemen Keuangan. (S. Empat, Ed.). Jakarta.

Buchanan, B., Cao, C. X., \& Chen, C. (2018). Corporate Social Responsibility, Firm Value, And Influential Institutional Ownership. Journal of Corporate Finance, 52, 73-95. Https://Doi.Org/10.1016/J.Jcorpfin.2018.07.004

Dewi, D. A. I. Y. M., \& Sudiartha, G. M. (2017). Pengaruh Profitabilitas, Ukuran Perusahaan, Dan Pertumbuhan Perusahaan Aset Terhadap Struktur Modal Dan Nilai Perusahaan. E-Jurnal Manajemen Unud, 6(4), 2222-2252.

Dhani, I. P., \& Utama, A. . G. S. (2017). Pengaruh Pertumbuhan Perusahaan, Struktur Modal, Dan Profitabilitas Terhadap Nilai Perusahaan. Jurnal Riset Akuntansi Dan Bisnis Airlangga, 2(1), 135148.

Fama, E. (1978). The Effects Of A Firm's Investment And Financing D. The American Economic Review, 68(3), 272-284.

Febrianti, M. (2012). Faktor-Faktor Yang Mempengaruhi Nilai Perusahaan Pada Industri 
Pertambangan Di Bursa Efek Indonesia. Jurnal Bisnis Dan Akuntansi, 14(2), 141-156.

Ghalandari, K. (2013). The Moderating Effects Of Growth Opportunities On The Relationship Between Capital Structure And Dividend Policy And Ownership Structure With Firm Value In Iran: Case Study Of Tehran Securities Exchange. Research Journal Of Applied Sciences, Engineering And Technology, 5(4), 1424-1431.

Gusti, B. F. (2013). Pengaruh Free Cash Flow Dan Struktur Kepemilikan Saham Terhadap Kebijakan Hutang Dengan Investment Opportunity Set Sebagai Variabel Moderating. Jurnal Akuntansi, $1(2), 1-25$.

Harahap, L., \& Wardhani, R. (2011). Analisis Komprehensif Pengaruh Family Ownership; Masalah Keagenan; Kebijakan Dividen; Kebijakan Hutang; Corporate Governance Dan Opportunity Growth Terhadap Nilai Perusahaan. Fakultas Ekonomi Universitas Indonesia, 1-36.

Hasbi, H. (2015). Islamic Microfinance Institution: The Capital Structure, Growth, Performance And Value Of Firm In Indonesia. Procedia - Social And Behavioral Sciences, 211, 1073-1080. Https://Doi.Org/10.1016/J.Sbspro.2015.11.143

Hermuningsih, S. (2013). Pengaruh Profitabilitas, Growth Opportunity, Sruktur Modal Terhadap Nilai Perusahaan Pada Perusahaan Publik Di Indonesia. Buletin Ekonomi Moneter Dan Perbankan, 127-148.

Isshaq, Z., Bokpin, G. A., \& Onumah, M. J. (2009). Corporate Oovernance, Ownership Structure, Cash Holdings, And Firm Value On The Ghana Stock Exchange. Journal Of Risk Finance, 10(5), 488499. Https://Doi.Org/10.1108/15265940911001394

Jensen, M. C. (1986). Agency Cost Of Free Cash Flow, Corporate Finance, And Takeovers. American Economic Review, 76(2), 323-329. Https://Doi.Org/10.2139/Ssrn.99580

Jensen, M. C., \& Meckling, W. H. (1976). Theory Of The Firm: Managerial Behavior, Agency Costs And Ownership Structure. Journal Of Financial Economics, 3(4), 305-360. Https://Doi.Org/10.1016/0304-405x(76)90026-X

Jiang, K. J. (2012). Capital Structure, Cost Of Debt And Dividend Payout Of Firms In New York Stock Exchanges. International Journal Of Economics And Financial, 1(3), 117-125.

Karadeniz, E., Kandir, S. Y., Balcilar, M., \& Onal, Y. B. (2009). Determinants Of Capital Structure: Evidence From Turkish Lodging Companies. International Journal Of Contemporary Hospitality Management, 21(5), 594-609. Https://Doi.Org/10.1108/09596110910967827

Modigliani, F., \& Miller, M. H. (1963). Corporate Income Taxes And The Cost Of Capital: A Correction. American Economic Review, 3(53), 433-443.

Moh'd., M. A., Perry, R. (1998). The Impact Of Ownership Structure On Corporate Debt Policy : A Time Series Cross Sectional Analysis. Financial Review, 33.

Myers, S. C. (1984). The Capital Structure Puzzel. The Journal Of Finance, Xxxix(3).

Nadillah, D. Y. (2017). Pengaruh Struktur Modal Dan Pertumbuhan Perusahaan Terhadap Nilai Perusahaan Yang Dimediasi Kinerja Keuangan Dengan Pengungkapan Corporate Social Responsibility Sebagai Variabel Pemoderasi Pada Perusahaan Manufaktur Di Bursa Efek Indonesia Tahun 2010-2014. Jom Fekon, 4(1), 1-15.

Nassar, S. (2016). The Impact Of Capital Structure On Financial Performance Of The Firms : Evidence From Borsa Istanbul. Journal Of Business And Financial Affairs, 5(2), 5-8. Https://Doi.Org/10.4172/2167-0234.100017

Nawaz, A., Ali, R., \& Naseem, M. A. (2011). Relationship Between Capital Structure And Firms Performance : A Case Of Textile Sector In Pakistan. International Journal, 3(January), 270-275.

Prasetia, T. E., Tommy, P., \& Saerang, I. S. (2018). Struktur Modal; Ukuran Perusahaan Dan Risiko Perusahaan Terhadap Nilai Perusahaan. Jurnal Emba, 2(2), 879-889.

Prastuti, N. K. R., \& Sudiartha, I. G. M. (2016). Pengaruh Struktur Modal, Kebijakan Dividen, Dan Ukuran Perusahaan Terhadap Nilai Perusahaan Pada Perusahaan Manufaktur. E-Jurnal Manajemen Unud, 5(3), 1572-1598.

Pratiwi, N. P. D., \& Mertha, M. (2017). Pengaruh Kebijakan Hutang Dan Profitabilitas Pada Nilai Perusahaan Dengan Kebijakan Dividen Sebagai Variabel Pemoderasi. E-Jurnal Akuntansi 
Universitas Udayana, 2(20), 1446-1475.

Rachman, N. A. (2016). Sektor Industri Food And Beverages Yang Terdaftar Di Bursa Efek Indonesia ( Bei ) Pada Tahun 2011- 2015. Jurnal Pendidikan Dan Ekonomi, 5(5), 405-416.

Rakhimsyah, L. A., \& Gunawan, B. (2011). Pengaruh Keputusan Investasi, Keputusan Pendanaan, Kebijakan Dividen Dan Tingkat Suku Bunga Terhadap Nilai Perusahaan. Jurnal Investasi Juni, $7(1), 31-45$.

Rizqia, D. A., Aisjah, S., \& Sumiati. (2013). Effect Of Managerial Ownership, Financial Leverage, Profitability, Firm Size, And Investment Opportunity On Dividend Policy And Firm Value. Research Journal Of Finance And Accounting, 4(11), 120-130.

Salvatore, D. (2011). Ekonomi Manajerial Dalam Perekonomian Global. (S. Empat, Ed.). Jakarta.

Seetanah, B., Seetah, K., Appadu, K., \& Padachi, K. (2014). Capital Structure And Firm Performance: Evidence From An Emerging Economy. The Business \& Management Review, 4(4), 168-179.

Seftiani, \& Ratih, H. (2011). Faktor-Faktor Yang Mempengaruhi Struktur Modal Pada Perusahaan Publik Sektor Manufaktur. Jurnal Bisnis Dan Akuntansi, 13(1), 39-56.

Sofyaningsih, S., \& Hardiningsih, P. (2011). Akuntansi Manajemen Perencanaan Dan Pembuatan Keputusan Jangka Pendek. Jurnal Dinamikan Keuangan Dan Perbankan, 3(1), 57-59.

Sualehkhattak, M., \& Hussain, C. M. (2017). Do Growth Opportunities Influence The Relationship Of Capital Structure, Dividend Policy And Ownership Structure With Firm Value: Empirical Evidence Of Kse? Journal Of Accounting \& Marketing, 6(1), 1-11. Https://Doi.Org/10.4172/21689601.1000216

Sugiarto, M. (2011). Pengaruh Struktur Kepemilikan Dan Kebijakan Dividen Terhadap Nilai Perusahaan Dengan Kebijakan Hutang Sebagai Intervening. Jurnal Akuntansi Kontemporer, 3(I), $1-25$.

Sujoko, U., \& Soebiantoro. (2007). Pengaruh Struktur Kepemilikan Saham, Leverage, Faktor Intern Dan Faktor Ekstern Terhadap Nilai Perusahaan. Jurnal Manajemen Dan Kewirausahaan, 9(1), 4148.

Sukriyawati, N. (2016). Pengaruh Struktur Modal Dan Pertumbuhan Perusahaan Terhadap Nilai Perusahaan Dengan Good Corporate Governance Sebagai Variabel Moderating. Jurnal Akuntansi Manajerial, 1(2), 71-82.

Syardiana, G., Rodoni, A., \& Putri, Z. E. (2015). Pengaruh Investment Opportunity Set, Struktur Modal , Pertumbuhan Perusahaan ,. Jurnal Akuntabilitas, Viii(1), 39-46.

Titman, S., J., A., Keown, J., \& John, D. M. (2014). Financial Management: Principles And Applications (Edition 12). Usa: Pearson Education.

Vintila, G., \& Gherghina, C. (2014). The Impact Of Ownership Concentration On Firm Value . Empirical Study Of The Bucharest Stock Exchange Listed Companies, 15(14), 271-279. Https://Doi.Org/10.1016/S2212-5671(14)00500-0

Wardhani, T. S., Chandrarin, G., \& Rahman, A. F. (2017). Pengaruh Kepemilikan Institusional Terhadap Nilai Perusahaan Dengan Keputusan Investasi, Keputusan Pendanaan Dan Kebijakan Dividen Sebagai Variabel Moderasi. Jurnal Ilmiah Ilmu Akuntansi Keuangan Publik, 1(2), 93-110.

Widyaningsih, D. (2018). Kepemilikan Manajerial , Kepemilikan Institusional , Komisaris Independen , Serta Komite Audit Pada Nilai Perusahaan Dengan Pengungkapan Csr Sebagai Variabel Moderating Dan Firm Size Sebagai Variabel Kontrol. Jurnal Akuntansi Dan Pajak, 19(1), 38-52.

Xiong, J. (2016). Institutional Investors, Dividend Policy And Firm Value Evidence From China. Open Journal Of Social Science, (August), 120-126.

Yando, A. D. (2018). Pengaruh Struktur Modal Terhadap Nilai Perusahaan Dengan Pertumbuhan Perusahaan Dan Profitabilitas Sebagai Variabel Moderating. Jim Upb, 6(1), 1-11.

Yuliyanti, L. (2014). Pengaruh Keputusan Keuangan Dan Struktur Kepemilikan Terhadap Nilai Perusahaan. Universitas Muhammadiyah Surakarta.

Yuniati, M., Kharis, R., \& Oemar, A. (2016). Journal Of Accounting, Volume 2 No.2 Maret 2016. Journal Of Accounting, 2(2). 